PATIK : Jurnal Hukum

https://ejournal.uhn.ac.id/index.php/patik

Volume 09 Nomor 02, Agustus 2020 Page : 125 - 136

p-issn : $2086-4434$

\title{
PERTANGGUNGJAWABAN PIDANA PELAKU YANG DENGAN SENGAJA MELAKUKAN PENYALAHGUNAAN IZIN TINGGAL (STUDI PUTUSAN NOMOR: 748/PID.SUS/2016/PN.DPS)
}

\author{
Daniel Fernando Sinurat, Erita Wagewati Sitohang, Herlina Manullang \\ Fakultas Hukum, Universitas HKBP Nommensen \\ eritawagewatisitohang@uhn.ac.id
}

\begin{abstract}
Abstrak
Indonesia merupakan negara maritim yang terdiri dari banyak Pulau dan diatur dalam Undang-Undang Dasar 1945 Pasal 26 ayat (1) menyatakan bahwa : "Yang menjadi warga negara ialah orang-orang bangsa Indonesia asli dan orang-orang bangsa lain yang disahkan dengan Undang-Undang sebagai warga negara" Pasal 26 ayat (2) : penduduk ialah warga negara Indonesia dan orang asing yang bertempat tinggal di Indonesia. . Menurut Pasal 48 Ayat 2 Undang-Undang Nomor. 6 Tahun 2011 tentang Keimigrasian yang berbunyi "Izin tinggal diberikan kepada orang asing sesuai dengan visa yang dimilikinya." Penyalahgunaan Izin tinggal merupakan suatu peristiwa hukum yang sudah sering terjadi di dalam tindak pidana keimigrasian. Izin tinggal yang diberikan kepada orang asing untuk berada di wilayah negara Indonesia sering sekali disalahgunakan para pemegang izin tersebut sehingga banyak terjadi kasus penyalahgunaan izin tinggal. Keberadaan warga negara asing di Indonesia tidak sedikit yang menyalahgunakan ijin keimigrasian, maka penulis tertarik untuk membuat karya ilmiah ilmiah yang berjudul pertanggung jawaban pidana atas tindak pidana keimigrasian.
\end{abstract}

Kata Kunci : Orang asing, Penyalahgunaan izin tingal, Keimigrasian, Pertanggungjawaban Pidana

\begin{abstract}
Indonesia is a maritime country consisting of many islands and regulated in the 1945 Constitution Article 26 paragraph (1) states that: as citizens of the country "Article 26 paragraph (2): residents are Indonesian citizens and foreigners who reside in Indonesia. . According to Article 48 Paragraph 2 of Law Number. 6 of 2011 concerning Immigration which reads "Residence permits are granted to foreigners in accordance with the visa they have." Abuse of residence permit is a legal event that has often occurred in immigration crimes. Residence permits granted to foreigners to be in the territory of Indonesia are often misused by the holders of these permits, resulting in many cases of abuse of residence permits. The presence of foreign citizens in Indonesia is not a few who abuse immigration permits, so the author is interested in making scientific papers entitled criminal liability for immigration crimes.
\end{abstract}

Keywords: Foreigners, Abuse of residence permit, Immigration, Criminal Liability. 


\section{PATIK : JURNAL HUKUM Vol : 09 No. 2, Agustus 2020, Hal 125 - 136}

\section{Pendahuluan}

Indonesia merupakan negara maritim yang terdiri dari banyak Pulau. Hal ini sudah diketahui semua orang bahwa indonesia merupakan negara persinggahan. Indonesia dikatakan negara persinggahan karena indonesia adalah negara yang letaknya sangat strategis dan merupakan akses pintu masuk ke dalam ataupun keluar negri. Indonesia sebagai salah satu negara di dunia juga memiliki potensi yang kuat sebagai tempat persinggahan (Transit) ataupun sebagai tempat tujuan para warga negara asing Ilegal dikarenakan bentuk negaranya adalah kepulauan yang memiliki berbagai pintu masuk seperti, bandara, pelabuhan, batas darat dan batas perairan.

Hal ini terbukti dengan banyaknya kasus-kasus warga negara asing yang masuk ke negara Indonesia yang terdampar maupun menjadikan Indonesia sebagai tempat mencari Suaka tanpa memiliki dokumen resmi untuk tinggal di Indonesia. Berdasarkan UndangUndang Dasar 1945 Pasal 26 ayat (1) menyatakan bahwa : "Yang menjadi warga negara ialah orang-orang bangsa Indonesia asli dan orang-orang bangsa lain yang disahkan dengan Undang-Undang sebagai warga negara” Pasal 26 ayat (2) : penduduk ialah warga negara Indonesia dan orang asing yang bertempat tinggal di Indonesia.

Orang asing yang akan masuk dan bertempat tinggal di Indonesia diatur dalam Undang-Undang mengenai masuk dan keluar wilayah Indonesia, dokumen perjalanan Republik Indonesia, visa, tanda masuk, dan izin tinggal. Menurut Pasal 48 Ayat 2 UndangUndang Nomor. 6 Tahun 2011 tentang Keimigrasian yang berbunyi “ Izin tinggal diberikan kepada orang asing sesuai dengan visa yang dimilikinya." Penyalahgunaan Izin tinggal merupakan suatu peristiwa hukum yang sudah sering terjadi di dalam tindak pidana keimigrasian. Izin tinggal yang diberikan kepada orang asing untuk berada di wilayah negara Indonesia sering sekali disalahgunakan para pemegang izin tersebut sehingga banyak terjadi kasus penyalahgunaan izin tinggal.

Izin adalah perbuatan hukum administrasi negara persegi satu yang mengaplikasikan peraturan dalam hal konkret berdasarkan persyaratan dan prosedur sebagaimana ditetapkan oleh ketentuan Peraturan Perundang-undangan. Terkait dengan pelanggaran Izin tinggal beberapa Jenis Izin yang dilanggar Pelanggaran Izin tinggal terbagi dalam 3 jenis, yaitu penyalahgunaan Izin tinggal, melebihi batas waktu izin tinggal (Overstay), dan tidak memiliki izin tinggal (Illegal Stay)". Izin Keimigrasian adalah bukti keberadaan yang sah bagi setiap orang asing di wilayah Indonesia. Izin tinggal adalah bagian dari izin keimigrasian itu sendiri.

Pertanggungjawaban Pidana Terhadap Pelaku Penyalahgunaan Izin Tinggal di Indonesia menegaskan bahwa setiap turis asing yang berkunjung ke Indonesia harus mendapatkan izin dari Pejabat Imigrasi dan Pejabat Dinas Luar Negeri sesuai dengan visa serta tujuan mereka datang ke Indonesia. Hal itu sesuai dengan Peraturan PerundangUndangan yang berlaku di Indonesia, yang tercantum dalam 8 ayat (2) Undang-Undang Nomor 6 Tahun 2011 Tentang Keimigrasian yang menegaskan bahwa setiap orang asing yang masuk wilayah Indonesia wajib memiliki Visa yang sah dan masih berlaku, kecuali ditentukan lain berdasrakan Undang-undang ini dan perjanjian Internasional.

Selanjutnya dalam Pasal 9 ayat (1) Undang-Undang Nomor 6 Tahun 2011 tentang Keimigrasian menegaskan bahwa setiap orang yang masuk atau keluar wilayah Indonesia wajib melalui pemeriksaan yang dilakukan oleh pejabat Imigrasi di tempat pemeriksaan imigrasi. Ketentuan pidana bagi orang asing yang melakukan pelanggaran diatur dalam Pasal 122 yang berbunyi bahwa setiap turis asing yang dengan sengaja menyalahgunakan atau melakukan kegiatan yang tidak sesuai dengan maksud dan tujuan pemberian izin tinggal yang diberikan kepadanya dipidana dengan pidana penjara paling lama 5 tahun dan pidana denda paling banyak Rp 500.000.000,00 (lima ratus juta rupiah). 


\section{PATIK : JURNAL HUKUM Vol : 09 No. 2, Agustus 2020, Hal 125 - 136}

Pertanggung jawaban pidana adalah proses dilakukannya upaya untuk tegaknya atau berfungsinya norma-norma hukum secara nyata sebagai pedoman perilaku dalam lalu lintas atau hubungan-hubungan hukum dalam kehidupan bermasyarakat dan bernegara. Ditinjau dari subjeknya, penegakan hukum itu dapat dilakukan oleh subjek yang luas dan dapat pula diartikan sebagai upaya penegakan hukum itu melibatkan semua subjek dalam setiap hubungan hukum. Siapa saja yang menjalankan aturan normatif atau melakukan sesuatu atau tidak melakukan sesuatu dengan mendasarkan diri pada norma aturan hukum yang berlaku, berarti dia menjalankan atau menegakkan aturan hukum.

Dalam arti sempit, dari segi subjeknya, penegak hukum itu hanya diartikan sebagai upaya aparatur penegakan hukum tertentu untuk menjamin dan memastikan tegaknya hukum itu, apabila di perlukan, aparatur penegak hukum itu diperkenankan untuk menggunakan daya paksa. ${ }^{1}$ Hukum keimigrasian seperti tercantum dalam Pasal 1 butir (1) Undang-Undang Nomor 6 Tahun 2011 tentang Keimigrasian, adalah hal ihwal lalu lintas orang yang masuk atau keluar Wilayah Indonesia serta pengawasannya dalam rangka menjaga tegaknya kedaulatan negara.

Berlakunya Undang-Undang Nomor 6 Tahun 2011 tentang Keimigrasian maka penegakan hukum terhadap pelaku tindak pidana keimigrasian menjadi sangat penting. Undang-undang ini mengatur berbagai kemungkinan kejahatan yang dilakukan baik oleh warga negara Indonesia dan warga negara asing serta menjangkau koorporasi selaku sponsor keberadaan dan kegiatan orang asing. Tidak ada lagi orang asing dengan luasa melakukan tindak pidana di bidang keimigrasian serta koorporasi yang yang memberi jaminan secara fiktif kepada orang asing, juga kepada WNI yang berharap dapat memiliki paspor dengan data fiktif atau memiliki paspor lebih dari satu.

Hal ini dapat di jerat dengan undang- undang keimigrasian. Secara faktual harus diakui dalam hal ihwal lalu lintas orang asing ke wilayah RI tentunya akan meningkatkan penerimaan uang yang dibelanjakan di Indonesia, meningkatnya investasi, dan meningkatnya aktivitas perdagangan serta adanya proses modernisasi masyarakat terpacu karena pertumbuhan ekonomi serta bentuk-bentuk kerjasama lainnya. Secara operasional fungsi penegakan hukum yang dilaksanakan oleh institusi imigrasi bersifat administrasi dan bersifat proyustitia. Tindakan administrasi mencakup penolakan pemberian izin masuk, izin bertolak, izin keimigrasian dan tindakan keimigrasian. Sementara itu dalam hal penegakan hukum yang bersifat proyustitia, yaitu kewenangan penyidikan, tercakup tugas penyidikan (pemanggilan, penangkapan, penahanan, pemeriksaan, penggeledahan, dan penyitaan), pemberkasan perkara, serta pengajuan berkas perkara ke penuntut umum. Dalam hal tindakan keimigrasian antara lain:

a. Tindakan hukum pidana, melalui serangkaian tindakan penyidikan dalam proses sistem peradilan pidana, kemudian setelah selesai menjalani pidana, diikuti tindakan deportasi ke negara asal dan penangkalan tidak diijinkan masuk ke wilayah Indonesia dalam batas waktu yang di tentukan oleh undang-undang.

b. Tindakan hukum administrasi, terhadap pelanggaran hukum tersebut tidak dilakukan penyidikan, melainkan langsung dikenakan tindakan administrasi dibidang keimigrasian, yang disebut tindakan keimigrasian berupa pengkarantinaan, deportasi, dan penangkalan. Instrumen perizinan dibidang keimigrasian terdapat dalam UU Nomor. 6 Tahun 2011 tentang Keimigrasian menegaskan bahwa pada dasarnya keberadaan warga negara asing di Indonesia tetap dibatasi keberadaaannya dan juga warga negara

\footnotetext{
${ }^{1} \mathrm{http} / /$ www.solusihukum.com yang diakses pada tanggal 10 Desember 2019, Pukul 20.00 WIB
} 


\section{PATIK : JURNAL HUKUM Vol : 09 No. 2, Agustus 2020, Hal 125 - 136}

asing yang berada di Indonesia wajib memiliki Izin Keimigrasian yang masih berlaku, dikecualikan kepada mereka yang sedang menjalani proses projustisia atau pidana di lembaga pemasyarakatan apabila izinnya telah habis masa berlakunya.

Keberadaan warga negara asing di Indonesia, tidak sedikit yang menyalahgunakan ijin keimigrasian. Melihat semakin maraknya kasus dibidang imigrasi maka akan adanya pertanggung jawaban pidana atas tindak pidana keimigrasian dan yang menjadi rumusan permasalahan adalah sebagai berikut: "Bagaimanakah pertanggungjawaban pidana terhadap pelaku yang dengan sengaja melakukan penyalahgunaan Izin tinggal studi putusan nomor: 748/PID.SUS/2016/PN.DPS”.

\section{Tinjauan Pustaka}

Dalam setiap sistem hukum modern dikenal dengan berbagai cara mengadakan peraturan tentang bagaimana mempertanggungjawabkan orang yang telah melakukan tindak pidana. Aturan hukum mengenai pertanggungjawaban pdiana berfungsi sebagai penentu syarat-syarat yang harus ada pada diri seseorang sehingga sah jika dijatuhi pidana. Pertanggungjawaban pidana mengandung asas kesalahan yang didasarkan pada keseimbagan monudualistik bahwa asas kesalahan harus ada pada diri seseorang sehingga sah jika dijatuhi pidana.

Pertanggungjawaban pidana mengandung asas kesalahan yang didasarkan pada keseimbangan monodualistik bahwa asas kesalahan yang didasarkan pada nilai keadilan harus disejajarkan berpasangan dengan asas Legalitas yang didasarkan pada nilai kepastian. Pertanggungjawaban pidana diterapkan dengan pemidanaan yang bertujuan untuk mencegah dilakukannya tindak pidana dengan menegakkan dengan norma hukum demi pengayoman masyarakat menyelesaikan konflik yang ditimbulkan tindak pidana memulihkan keseimbangan mendatangkan rasa damai dalam masyarakat. Konsep Pertanggungjawaban merupakan konsep sentral yang dikenal dengan ajaran kesalahan.

Dalam bahasa Latin ajaran kesalahan dikenal dengan Mens Rea. Doktrin Mens Rea dilandaskan pada suatu perbuatan tidak mengakibatkan seseorang

bersalah kecuali jika pikiran orang itu jahat. Untuk dapat memidana seseorang, yaitu ada perbuatan lahir lah yang terlarang dan ada sikap jahat." ${ }^{2}$ Pertanggungjawaban pidana atau criminal liability sesungguhnya tidak hanya menyangkut soal hukum semata-mata, melainkan juga menyangkut soal nilai-nilai moral atau kesusilaan umum yang dianut oleh suatu masyarakat atau kelompok- kelompok masyarakat. Menurut Roeslan Saleh Pertanggungjawaban pidana diartikan sebagai diteruskannya celaan objektif yang pada perbuatan pidana dan secara subjektif memenuhi syarat untuk dapat dipidana karena perbuatannya itu. Roeslan Saleh mempertanyakan apakah yang dimaksud dengan seseorang itu bertanggungjawab atas perbuatannya.

Roeslan Saleh memberikan jawaban atas pandangan tersebut bahwa bertanggungjawab atas suatu perbuatan pidana berarti yang bersangkutan secara sah dapat dikenai pidana karena perbuatan itu. Pidana itu dapat dikenakan secara sah berarti untuk tindakan itu telah adanya aturannnya dalam suatu sistem hukum tertentu dan sistem hukum itu berlaku atas perbuatan itu. Ilmu hukum pidana secara umum menyatakan bahwa pertanggungjawaban terhadap suatu tindak pidana adalah suatu proses dilanjutkan celaan (verwijtbaarheid) yang objektif terhadap perbuatan yang dinyatakan sebagai tindak pidana oleh hukum pidana dan si pelaku merupakan subjek hukum yang dianggap memenuhi persyarakatan untuk dijatuhi pidana.

\footnotetext{
${ }^{2}$ Mahsur Ali, Dasar- Dasar Hukum Pidana, Sinar Grafika, Jakarta Timur, 2012, Hal. 156
} 


\section{PATIK : JURNAL HUKUM Vol : 09 No. 2, Agustus 2020, Hal 125 - 136}

Chairul Huda menyatakan bahwa Pertanggungjawaban pidana adalah suatu bentuk mekanisme yang diciptakan untuk bereaksi atas pelanggaran suatu perbuatan tertentu yang telah disepakati. Martias Gelar Imam Radjo Mulano ${ }^{3}$ menyatakan: Teorekeningsvatbaarheid diartikan kemampuan bertanggungjawab; kemampuan bertanggungjawab adalah salah satu unsur kesalahan, maka seseorang dapat dipertanggungjawabkan atas suatu perbuatan tertentu, seseorang dapat menentukan kehendaknya sesuai dengan akalnya. Moelyatno ${ }^{4}$ menyatakan: Bahwa ajaran Kontrowicz, antara perbuatan pidana dan pertanggungjawaban pidana dalam hukum pidana, ada hubungan erat seperti halnya dengan perbuatan dan orang yang melakukan perbuatan, perbuatan pidana baru, mempunyai arti kalau disampingnya adalah pertanggungjawaban, sebaliknya tidak mungkin ada pertanggungjawaban, jika tidak ada perbuatan pidana.

Pembahasan mengenai pertanggungjawaban pidana setidaknya terdapat dua aliran yang selama ini dianut, yaitu aliran indeterminisme dan aliran determinisme. Kedua aliran tersebut membicarakan hubungan antara kebebasan kehendak dengan ada atau tidaknya kesalahan, sebagai berikut:

a. Kaum indeterminisme (penganut indeterminisme), yang pada dasarnya berpendapat, bahwa manusia mempunyai kehendak bebas dan ini merupakan sebab dari segala keputusan kehendak. Tanpa ada kebabasan kehendak maka tidak ada kesalahan; apabila tidak ada kesalahan, maka tidak ada pencelaan, sehingga tidak ada pemidanaan.

b. Kaum determinis (penganut determinme) mengatakan, bahwa manusia tidak mempunyai kehendak bebas. Keputusan kehendak ditentukan sepenuhnya oleh watak (dalam ari nafsu manusia dalam hubungan kekuatan satu sama lain) dan motif-motif, ialah perangsang datang dari dalam atau dari luar yang mengakibatkan watak tersebut. Ini berarti bahwa seseorang tidak dapat dicela atas perbuatannya atau dinyatakan mempunyai kesalahan, sebab ia tidak punya kehendak bebas. Namun meskipun diakui bahwa tidak punya kehendak bebas, itu tidak berarti bahwa orang yang melakukan tindak pidana tidak dapat dipertanggungjawabkan atas perbuatannya.

Indonesia sebagai penganut sistem civil law, ${ }^{5}$ mengakui asas kesalaahan sebagai satu-satunya asas dalam pertanggungjawaban pidana. Praktiknya, Indonesia juga mengajui adanya pengecualian terhadap asas tersebut. Hal ini terjadi karena perkembangan masyarakat yang sangat cepat menuntut diberlakukannya berbagai model atau sistem pertanggungjawaban pidana. Kecenderungan yang demikian itu, membuat perancang KUHP Baru menganggap penting untuk mencantumkan bentuk atau model sistem pertanggungjawaban yang merupakan pengecualian dari asas kesalahan ke dalam KUHP Nasional. Penyimpangan terhadap asas kesalahan yang dicantumkan dalam konsep KUHP mendapat tanggapan pro dan kontra dari kalangan para ahli hukum. Schaffmeister mengganggap bahwa penyimpangan itu merupakan hal yang bertentangan dengan asas mens-rea.

\footnotetext{
3 Martias Gelar Imam Radjo Mulano, Pembahasan Hukum, Penjelasan, Istilah Istilah Hukum Belanda, Ghalia, Jakarta, 1982, Hal:204

${ }^{4}$ Moelyatno, Perbuatan Pidana dan Pertanggungjawaban dalam Hukum Pidana, Bina Aksara, Jakarta, 1983, Hal: 22-23

${ }^{5}$ Simamora, Janpatar., Tafsir Makna Negara Hukum dalam Perspektif Undang-Undang Dasar Negara Republik Indonesia Tahun 1945, Jurnal Dinamika Hukum FH Universitas Jenderal Soedirman, Vol. 14 No. 3 September 2014, hlm. 547-561
} 


\section{PATIK : JURNAL HUKUM Vol : 09 No. 2, Agustus 2020, Hal 125 - 136}

Barda Nawawi Arief, menyatakan perkecualian atau penyimpangan dari suatu asas jangan dilihat semata-mata sebagai suatu pertentangan (kontradiksi), tetapi harus juga dilihat sebagai pelengkap (complement) dalam mewujudkan asas keseimbangan, yaitu keseimbangan antara kepentingan pribadi dengan kepentingan masyarakat. Keseimbangan antara kedua kepentingan itulah yang oleh Barda Nawawi Arief dinamakan Asas Monodualistik. ${ }^{6}$

Seseorang atau pelaku tindak pidana tidak akan diminta pertanggungjawaban pidana atau di jatuhi pidana apabila tidak melakukan perbuatan pidana dan perbuatan pidana tersebut haruslah melawan hukum, namun meskipun dia melakukan perbuatan pidana tidak lah dia selalu dapat dipidana, orang yang melakukan perbuatan pidana hanya akan dipidana apabila dia terbukti secara sah dan meyakinkan melakukan kesalahan. Berdasarkan uraian di atas adapun syarat- syarat pertanggungjawaban pidana menurut Moeljatno adalah :" 7

1. Seseorang telah melakukan perbuatan pidana

2. Dilihat kemampuan bertanggungjawab oleh seseorang yang telah melakukan perbuatan pidana

3. Adanya bentuk kesalahan baik berupa kesengajaan atau kelalaian dalam perbuatan pidana.

4. Tidak ada alasan pembenar atau alasan pemaaf yang menghapuskan pertanggungjawaban pidana terhadap pelaku perbuatan pidana.

Dari pasal tersebut dapat diartikan bahwa suatu perbuatan dapat dipidana apabila telah ada peraturan yang mengatur sebelumya tentang dapat atau tidaknya suatu perbuatan dijatuhi pidana. Apabila seseorang telah melakukan perbutan pidana, maka ia hanya dapat diadili berdasarkan Peraturan Perundang-Undangan Pidana yang berlaku pada saat perbuatan dilakukan. Sehingga Peraundang- Undangan yang mengatur pidana tidak berlaku surut atau mundur. Dari penjelasan tersebut dapat diartikan bahwa suatu perbuatan disebut perbuatan pidana apabila perbuatan tersebut yang dilarang oleh aturan dalam Hukum Pidana. Moeljatno juga menegaskan bahwa terdapat unsur-unsur atau syarat yang harus ada dalam suatu perbuatan pidana. Unsur atau syarat tersebut adalah sebagai berikut:

a. Kelakuan dan akibat (perbuatan)

b. Hal atau keadaan yang menyertai perbuatan.

c. Keadaan tambahan yang memberatkan pidana

d. Unsur melawan hukum yang objektif

e. Unsur melawan hukum yang subjekti

Dalam kemampuan bertanggungjawab, pertama dilihat faktor akal, yaitu apakah pelaku dapat membedakan antara perbuatan yang diperbolehkan dan yang tidak. Kemudian dilihat pula terhadap faktor perasaan atau kehendak si pelaku, yaitu apakah dapat menyesuaikan tingkah lakunya dengan kesadaran atas mana yang diperbolehkan dan yang tidak. Oleh karena itu apabila seorang pelaku perbuatan pidana melakukan perbuatan pidana dan tidak mampu menentukan kehendaknya menurut kesadaran tentang baik dan buruknya perbuatan itu, maka pelaku dianggap tidak mempunyai kesalahan dan tidak dapat dipertanggungjawabkan pidanya.

Selain itu dalam unsur pertanggungjawaban pidana juga dilihat sudut pandang terhadap bentuk kesalahan dalam perbuatan pidana yang dilakukan tersangka atau terdakwa. Yaitu apakah perbuatan yang dilakukan tersangka atau terdakwa tersebut terdapat bentuk kesalahan. Bentuk kesalahan apabila dihubungkan dengan keadaan jiwa

\footnotetext{
${ }^{6}$ Barda Nawawi Arief, Bunga Rampai Kebijakan Hukum Pidana, Citra Aditya Bakti, 1996, hal: 112-113

${ }^{7}$ Moeljatno, Opcit, Hal 164
} 


\section{PATIK : JURNAL HUKUM Vol : 09 No. 2, Agustus 2020, Hal 125 - 136}

seorang pelaku perbutan pidana, dapat berupa kesengajaan(Opzet) atau karena kelalaian (culps). Dalam kesengajaan terdapat dua teori yang barkaitan yaitu teori kehendak dan teori pengetahuan. Dalam teori kehendak kesengajaan adalah kehendak yang diarahkan pada terwujudnya perbuatan seperti yang dirumuskan Undnag-Undang.

Sedangkan menurut teori pengetahuan, untuk membuktikannya adanya kesengajaan dapat ditempuh dua cara, yaitu adanya hubungan kausal dalam batin terdakawa antara motif dan tujuan atau pembuktian adanya kesadaran terhadap yang dilakukan beserta akibat. Kemudian dalam pertanggungjawaban pidana dilihat juga dari sudut pandang adanya alasan pembenar atau alasan pemaaf yang menghapuskan pertanggungjawaban pidana. Alasan pembenar atau alasan pemaaf yang menghapuskan pidana terdapat dalam Kitab Undang-undang Hukum Pidana, yaitu dalam Buku I Bab III Pasal 44, Pasal 48, Pasal 49, Pasal 50, dan Pasal 51 KUHP. Dalam Pasal- Pasal tersebut disebutkan hal-hal yang menghapuskan pengenaan pidana, yaitu: tidak mampu bertanggungjawab, adanya daya paksa (Overmacht), pembelaan terpaksa, ketentuan Undnag-Undang, dan perintah jabatan yang sah. Dengan adanya alasan pembenar atau alasan pemaaf maka menghapuskan pertanggungjawaban pidana terhadap seseoran yang telah melakukan perbuatan pidana.

Setiap orang dianggap mengetahui dan mengerti akan adanya Undang-undang serta peraturan yang berlaku, sehingga setiap orang yang mampu mempertangungjawabkan, tidak dapat menggunakan alasan bahwa ia tidak mengetahui akan adanya suatu peraturan Perundang-undangan dengan ancaman hukuman tentang perbuatan yang telah dilakukannya. Adanya suatu tindakan yang melawan hukum belum cukup mejatuhkan pidana, tetapi diisyaratkan pembuat itu dapat dipersalahkan (dipertanggungjawabkan) atas perbuatannya. Seseorang yang melakukan suatu tindak pidana, tidak selalu dapat dipidana, hal ini tergantung dari apakah orang itu dalam melakukan tindak pidana tersebut mempunyai kesalahan atau tidak.

Sebab untuk dapat menjatuhkan pidana terhadap seseorang tidak cukup dengan dilakukan dengan tindak pidana saja, tetapi selain dari itu harus ada pula kesalahan atau menurut Moeljatno sikap batin yang tercela siapa yang melakukan kesalahan, maka dialah yang bertanggungjawab. Dalam hal ini dikenal suatu asas "tiada pidana tanpa kesalahan" (qeen straf zonder schould). Asas tiada pidana tanpa kesalahan tidak terdapat dalam KUHP, juga tidak terdapat dalam Perundang-undangan lainnya melainkan terdapat dalam hukum yang tidak tertulis. Meskipun tidak tertulis asas ini hidup dalam anggapan masyarakat dan diterima oleh hukum pidana disamping asas-asas yang tertulis dalam Undang-undang. Dalam hal dipidana atau si pelaku tindak pidana bukan lah tergantung pada apakah ada perbuatan pidana atau tidak melainkan pada apakah si terdakwa tercela atau tidak tercela telah melakukan tindak pidana itu. Dengan demikian dasar dari pada adanya tindak pidana adalah asas Legalitas.

Menurut D. Simons dikatakan bahwa kesalahan adalah keadaan psikis pelaku dan hubungannya dengan perbuatan yang dilakukan yang sedemikian rupa, sehingga berdasarkan keadaan psikis tersebut pelaku dapat dicela atas perbuatannya. Bagian-bagian dari pengertian kesalahan menurut D. Simons yaitu (1) adanya keadaan psikis tertentu dari pelaku, (2) adanya hubungan yang sedemikian rupa antara keadaan psikis tersebut dengan perbuatan yang dilakukan dan (3) berdasarkan keadaan psikis tersebut pelaku dapat dicela atas perbuatannya. ${ }^{8}$

Menurut Pompe bahwa pengertian kesalahan mempunyai tanda sebagai hal yang tercela (verwijtbaarheid) yang pada hakikatnya tidak mencegah (vermijdbaarheid)

\footnotetext{
${ }^{8}$ Frans Maranis, Hukum Pidana Umum Dan Tertulis Di Inonesia, Rajawali Pers, 2012, Hal: 114-
} 


\section{PATIK : JURNAL HUKUM Vol : 09 No. 2, Agustus 2020, Hal 125 - 136}

kelakuan yang bersifat melawan hukum (der wederrechtelijke gedraging). Kemudian dijelaskan pula tentang hakikat tidak mencegah kelakuan yang bersifat melawan hukum (vermijdbaarheid der wederrechtelijke gederaging) didalam perumusan hukum positif, disitu berarti mempunyai kesengajaan dan kealpaan (opzet enonachtzaamheid) yang mengarah kepada sifat melawan hukum (wederrechtelijke) dan kemampuan bertanggungjawab (toerekenbaarheid)." "Disini berlaku apa yang disebut asas " Tiada Pidana Tanpa Kesalahan" (Keine Strafe Ohne Schuld atau Geen Staraf Zonder Schuld atau Nulla Poena Sine Culpa).

Simons, guru besar ilmu hukum pidana memberikan terjemahan Straafbaarfeit sebagai perbuatan pidana. Menurutnya Staafbaarfeit adalah perbuatan melawan hukum yang berkaitan dengan kesalahan (Schuld) seseorang yang mampu bertanggungjawab. ${ }^{10}$ Selain itu Simons juga merumuskan Straafbaarfeit itu sebagai suatu tindakan melanggar hukum yang telah dilakukan dengan sengaja ataupun tidak dengan sengaja oleh seseorang yang dpat dipertanggungjawabkan atas tindakannya dan yang oleh Undang-Undang telah dinyatakan sebagai suatu tindakan yang dapat dihukum. ${ }^{11}$ Vos memberikan definisi bahwa Staafbaarfeit adalah kelakuan atau tingkah laku manusia, yang oleh peraturan Perundangundangan diberikan Pidana ${ }^{12}$.

Van Hattum berpendapat bahwa istiah Staafbaarfeit secara eksplisit haruslah diartikan sebagai suatu tindakan yang karena telah melakukan tindakan semacam itu membuat seseorang menjadi dapat dihukum atau suatu Feit terzake van hetwelk een person staafbaar is. ${ }^{13}$ Moeljatno mengatakan bahwa perbuatan pidana adalah perbuatan yang dilarang oleh suatu aturan hukum larangan mana disertai ancaman (sanksi) yang berupa pidana tertentu, bagi barang siapa yang melanggar larangan tersebut. Selanjutnya E. Utrecht merumuskan Straafbaarfeit dengan istilah peristiwa pidana yang sering juga ia sebut delik. Karena peristiwa itu suatu perbuatan handeen atau doen positif atau suatu melainkan natalen negatif, maupun akibatnya (keadaan yang ditimbulkan karena perbuatan atau melalaikan itu) ${ }^{14}$

Menurut konferensi internasional tahun 1924 di Roma tentang Emigrasi dan Imigrasi adalah "Human mobility to enter a country with its putpose to make a living of for residance" yang berarti bahwa imigrasi hanya memiliki arti gerak pindah orang yang memasuki suatu negara dengan niat untuk mencari nafkah dan menetap disana." 15 Pandangan ini merupakan suatu pandangan klasik yang dimana hanya sebatas melihat aspek perpindahana penduduk saja tanpa melihat aspek lainnya.

Pandangan modern saat ini tentang imigrasi melihat bahwa imigrasi tidak sebatas pada pergerakan individu tetapi secara kolektif tidak terbatas sukarela tetapi juga kebutuhan dan terorganisir, dengan demikian banyak aspek lainnya yang terkait. Sementara dalam Pasal 1 angka 1 Undang- undang Nomor 6 tahun 2011 tentang Keimigrasian menyebutkan bahwa Keimigrasian adalah Hal ikhwal lalu lintas orang yang masuk wilayah Negara Republik Indonesia serta pengawasaanya dalam rangka tegaknya kedaulatan negara.

Tindak pidana keimigrasian adalah tindak pidana sebagaimana dimaksudkan di dalam Pasal 131 Undang-undang nomor 6 Tahun 2011 Tentang Keimigrasian adalah

\footnotetext{
${ }^{9}$ Bambang Poernomo, Asas-Asas Hukum Pidana, Ghalia Indonesia, 1994, Hal: 136

${ }^{10}$ Zainal Abidin Farid, 2007, Hukum Pidana I, Cetakan Ke Dua, Sinar Grafika, Jakarta, Hal. 224

11 P.A.F Lamintang, 1997, Dasar-Dasar Hukum Pidana Indonesia, Cetakan Tiga, Citra Aditia Bakti, Bandung Hal. 185

12 Zainal Abidin Farid, Op. Cit, Hal 225

${ }^{13}$ Ibid, P.A.F Lamintang, Hal. 184

${ }^{14}$ Erdianto Effendi, 2011, Hukum Pidana Indonesia, Refika Aditama, Bandung, Hal. 98

${ }^{15}$ M. Iman Santoso, Prespektif Imigrasi, Bandung, Pustaka Reka Cipta, 2014, Hal 2
} 


\section{PATIK : JURNAL HUKUM Vol : 09 No. 2, Agustus 2020, Hal 125 - 136}

"Setiap orang yang dengan sengaja tanpa hak dan melawan hukum memiliki, menyimpan, merusak, menghilangkan, mengubah, menggandakan, mengunakan dan atau mengakses data keimigrasian, baik secara manual maupun elektronik, untuk kepentingan diri sendiri atau orang lain dipidana dengan pidana penjara paling lama 5 (lima) tahun dan pidana denda paling banyak Rp. 500.000.000,00 (lima ratus juta rupiah).

Tindak pidana adalah suatu perbuatan dalam keadaan dan situasi yang tertentu oleh Undang- undang dinyatakan terlarang, yang karenanya telah terjadi dapat mengakibatkan penghukuman badan dan atau moral bagi pelakunya. Bahwa tindak pidana bidang keimigrasian adalah serangkaian perbuatan terlarang oleh Undang-Undang dan tercela dalam kaitan dengan kegiatan keimigrasian. Sedangkan yang dimaksud keimigrasi adalah ha ikhwal lalu lintas orang yang masuk keluar wilayah Indonesia serta pengawasannya dalam rangka menjaga kedaulatan negara. Bahwa salah satu Urgensi pembentukan Undang- undang tentang keimigrasian adalah perkembangan global yang mewujudkan mobilitas penduduk dunia yang menimbulkan dampak baik yang menguntungkan dan merugikan kehidupan bangsa dan negara Republik Indonesia dan untuk adanya kepastian hukum yang mnejamin penghormatan, pengakuan dan perindungan Hak Asasi Manusia.

Tindak pidana keimigrasian adalah kedatangan atau kehadiran orang di wilayah Republik Indonesia dimana orang tersebut tidak terdaftar sebagai warga negara Indonesia dan tidak memiliki atau di lindungi dengan dokumen keimigrasian yang tidak ditindak lanjutkan oleh pejabat imigrasi. Institusi keimigrasian Indonesia, selain mengawasi lalu lintas orang di tuntut untuk dapat mengantisipasi perkembangan kejahatan transnasional terorganisasi, hal ini sehubungan dalam praktik pengawasan sering ditemukan pelaku kejahatan transnasional yang melakukan pemalsuan dokumen keimigrasian seperti paspor, visa, cap keimighrasian, atau izin tinggal.

Penegakan hukum pidana keimigrasian adalah penegakan hukum melalui proses penyidikan berdasarkan ketentuan Pasal 47 Undang- undang nomor 6 tahun 2011 yang dilaksanakan sesuai asas dan kaedah hukum acara pidana. Pasal 50 Undang-undang nomor 6 tahun 2011 mengatakan bahwa orang asing yang sengaja menyalahgunakan atau melakukan kegiatan yang tidak sesuai dengan maksud pemberian ijin keimigrasian yang diberikan kepadanya, dipidana dengan pidana penjara paling lama 5 (lima) tahun atau denda paling banyak Rp. 25.000.000,- (dua puluh lima juta rupiah) Pasal 42 (1) UndangUndang nomor 6 tahun 2011 mengatur tentang tindakan keimigrasian yang menyatakan bahwa tindakan keimigrasian dilakukan terhadap orang sing yang berada di wilayah Indonesia yang melakukan kegiatan berbahaya atau patut di duga akan berbahaya bagi keamanan dan ketertiban umum, tidak menghormati atau menaati Peraturan perundangundangan yang berlaku.

Kitab Undang- Undang Hukum Pidana (crimineel wetboek) tahun 1809 di cantumkan: "sengaja ialah kemauan untuk melakukan atau tidak melakukan perbuatanperbuatan yang dilarang akan diperintahkan oleh Undang-undang". Dalam memorie Van toelichting (MvT) Menteri kehakiman suatu pengajuan crimineel wetboek tahun 1881 (yang menjadi Kitab Undang-undang Hukum Pidana Indonesia tahun 1915), dijelaskan: "sengaja diartikan dengan kehendak melakukan suatu kejahatan tertentu".

Beberapa sarjana merumuskan de will sebagai keinginan, kemauan, kehendak, dan perbuatan merupakan pelaksanaan dari kehendak. De will (kehendak) dapat ditujukan terhadap perbuatan yang di larang dan akibat yang dilarang. Ada dua teori yang berkaitan dengan pengertian "sengaja" yaitu terori kehendak dan teori pengetahuan atau membayangkan. ${ }^{16}$ Menurut teori kehendak, sengaja adalah kehendak untuk mewujudkan

${ }^{16}$ Laden Marpaung, Kejahatan Terhadap Kesusilaan Dan Masalah Prevensinya, Sinar Grafika, Jakarta, 2008, Hal. 12 


\section{PATIK : JURNAL HUKUM Vol : 09 No. 2, Agustus 2020, Hal 125 - 136}

unsur- unsur delik dalam rumusan Undang-Undang sebagai contoh A mengarahkan pisol kepada B dan A menembak mati B, A adalah " sengaja" apabila A benar-benar menghendaki kematian $\mathrm{B}$.

Menurut teori pengetahuan atau teori membayangkan, manusia tidak mungkin dapat menghendaki suatu akibat karena manusia hanya dapat mengiginkan, mengharapkan, atau adanya suatu akibat. Adalah "sengaja" apabila suatu akibat yang di timbulkan karena suatu tindakan di bayangkan sebagai maksud tindakan itu dan karena itu tindakan yang bersangkutan dilakukan sesuai dengan bayangan yang terlebih dahulu telah dibuat. Teori ini menitik beratkan pada apa yang diketahui atau dibayangkan si pembuat, ialah apa yang akan terjadi pada waktu ia berbuat. Kedua teori tersebut, Moeljatno lebih cendung kepada teori pengetahuan atau membayangkan alasannya adalah: karena dalam kehendak dengan sendirinya diliputi pengetahuan. Sebab untuk menghendaki sesuatu, orang lebih dahulu sudah harus mempunyai pengetahuan (gambaran) tentang sesuatu itu. Tapi apa yang diketahui seseorang belum tentu saja dikehendaki olehnya. Lagi pula kehendak merupakan arah, maksud atau tujuan, hal mana berhubungan dengan motif (alasan pendorong untuk berbuat) dan tujuan perbuatannya. ${ }^{17}$

Konsekuensinya ialah, bahwa ia menentukan sesuatu perbuatan yang dikehendaki oleh terdakwa, maka (1) harus dibuktikan bahwa perbuatan itu sesuai dengan motifnya untuk berbuat dan tujuan yang hendak dicapai. (2) Antara motif, perbuatan dan tujuan harus ada hubungan kausual dalam batin terdakwa. Dari uraian tersebut, pembuktian terhadap teori kehendak itu tidak muda dan memakan banyak waktu dan tenaga. Lain halnya kalau kesengajaan diterima sebagai pengetahuan. Dalam hal ini pembuktian lebih singkat karena hanya berhubungan dengan unsur- unsur perbuatan yang dilakukannya saja tidak ada hubungan kausal antara motif dengan perbuatan.

Secara teoritis bentuk kesalahan berupa kesengajaan itu dibedakan tiga corak, yaitu kesengajaan sebagai maksud, kesengajaan dengan sadar kepastian dan, kesengajaan dengan sadar kemugkinan (doluseventualis). Perkembangan pemikiran dalam teori ini ternyata juga diikuti dalam praktik pengadilan di Indonesia. Di dalam putusan hakim menjatuhkan putusan tidak semata- mata kesengajaan sebagai kepastian, tetapi juga mengikuti corak- corak yang lain.

Membahas mengenai pidana tentunya tidak terlepas dari hukum pidana itu sendiri oleh karena itu tanpa hukum niscaya pidana akan diberlakukan secara sewenang- wenang oleh penguasa pada saat memerintah, oleh karena itu antara hukum pidana maupun pemidanaan berbeda artinya sehingga diperlukan penegasan dalam membedakannya. Adapun hukum pidana adalah keseluruhan peraturan- peraturan yang menentukan perbuatan yang merupakan tindak pidana dan hukuman apa yang dapat dijatuhkan terhadap yang melakukannya. ${ }^{18}$ Sedangkan Sudarsono mengatakan bahwa pada prinsipnya hukum pidana adalah hukum yang mengatur tentang kejahatan dan pelanggaran terhadap kepentingan umum dan perbuatan tersebut diancam dengan pidana yang merupakan suatu penderitaan. $^{19}$

Sedangkan Pompe memberikan definisi bahwa hukum pidana merupakan keseluruhan peraturan yang bersifat umum yang isinya adalah larangan dan keharusan terhadap pelanggarannya. Negara atau msyarakat hukum mengancam dengan penderitaan kasus berupa pemidanaan, penjatuhan pidana, peraturan itu juga mengatur ketentuan yang

\footnotetext{
17 Moeljatno, Asas- Asas Hukum Pidana, Rineka Cipta, Jakarta 1993, Hal 172

${ }^{18}$ Riduan Syahrani, 1999, Rangkuman Intisari Ilmu Hukum, . Citra Aditya Bakti, Bandung, Hal. 92

19 Sudarsono, 1994, Pengadian Negeri, Pengadilan Tinggi, MA dan Peradilan Tata Usaha Negara, Rineka Cipta, Jakarta, Hal. 102
} 


\section{PATIK : JURNAL HUKUM Vol : 09 No. 2, Agustus 2020, Hal 125 - 136}

memberikan dasar penjatuhan dan penerapan pidana. ${ }^{20}$ Dengan demikian hukum pidana bukanlah mengadakan norma hukum sendiri, melainkan sudah terletak pada norma lain dan sanksi tindak pidana diadakan untuk menguatkan di taatinya norma- norma lain tersebut, norma lain itu misalnya norma agama, kesusilaan atau sebagainya.

Pidana itu sendiri berasal dari kata straf (Belanda) yang pada dasarnya dapat dikatakan suatu penderitaan (Nestapa) yang disengaja di kenakan atau dijatuhkan kepada seseorang yang telah terbukti bersalah melakukan suatu tindak pidana. Kata "Pidana" Pada umumnya diartikan sebagai hukum, sedangkan "Pemidanaan" diartikan sebagai penghukuman. Pemidaan adalah suatu proses atau cara untuk menjatuhkan hukuman atau sanksi terhadap orang yang telah melakukan tindak pidana kejahatan (rechtsdelict) maupun pelanggaran (wetsdelict). Pidana dan pemmidanaan adalah suatu perasaan tidak enak (sengsara) yang dijatuhkan hakim dengan vonis kepada orang yang telah melanggar Perundang-Undangan hukum pidana.

\section{Metode}

Penelitian ini menggunakan penelitian yuridis normatif (Legal resereach) yang mengutamakan studi kepustakaan dan mencari konsep-konsep, pendapat-pendapat procedural hukum yang berdasarkan bahan hukum yang dilakukan dengan prosedur pengumpulan hukum secara studi kepustakaan. Metode pendekatan masalah yang digunakan dalam penelitian ini adalah: Metode Pendekatan Perundang- undangan (Statute approach). Pendekatan Perundang- undangan dilakukan dengan menelaah semua UndangUndang dan regulasi yang bersangkutan paut dengan isu hukum yang sedang di tangani. Pendekatan kasus (Case approach) adalah pendekatan yang dilakukan dengan cara melakukan pengkajian yang berkaitan dengan isu hukum yang dihadapi dan telah menjadi putusan pengadilan yang telah mempunyai kekuatan hukum tetap ${ }^{21}$, yaitu menganalisis Putusan Nomor 748/PID.SUS/2016.DPS. Penelitian ini menggunakan metode analisis yang dilakukan untuk mengumpulkan data dengan cara studi kepustakaan yaitu dengan cara menganalisis kasus dalam Putusan Nomor 748/PID.SUS/2016.DPS. yang dikaitkan dengan Perundang- undangan dan berbagai literatur yang berkaitan dengan masalah yang diteliti serta mengutip beberapa pendapat sarjana sehingga disusun secara sistematis dalam menjawab permasalahan. Bahan hukum yang diperoleh baik bahan primer, bahan sekunder, maupun bahan tambahan kemudian diolah dan disusun secara sistematis, sehingga bahan tersebut diperoleh suatu gambaran kemudian akan didapat suatu kesimpulan yang lebih obyektif.

\section{Kesimpulan Dan Saran}

Pelaksanaan Undang-undang Republik Indonesia Nomor 6 Tahun 2011 tentang penyalahgunaan izin tinggal keimigrasian di Indonesia sudah berjalan dengan maksimal tetapi terdapat kendala yang terjadi dalam sistem pelaksanaan penyelesaian suatu masalah izin tinggal keimigrasian. Pelaksanaan Undang-undang Republik Indonesia Tahun 2011 Tentang Keimigrasian di Indonesia seharusnya lebih diperhatikan tentang pengawasan orang asing yang datang di wilayah Indonesia agar tidak terjadi pelanggaran izin tinggal. Pengawasan yang lebih selektif dimulai pada saat pemberian visa lebih diutamakan tujuan orang asing masuk ke Indonesia dengan jaminan apabila mereka melanggar izin tinggal akan dikenakan tindakan atau sanksi hukum sesuai dengan ketentuan yang ada, dalam pemberian tanda masuk bagi orang asing di tempat pemeriksaan Imigrasi lebih teliti dalam proses pemeriksaan baik dokumen maupun visa yang ada, pengawasan dilapangan harus

${ }^{20}$ Teguh Prasetyo, 2010, Hukum Pidana, Raja Grafinfo Persada, Jakarta, Hal. 22

${ }^{21}$ Peter Mahmud Marzuki, Penelitian Hukum, Kencana, Jakarta, 2005, hal. 136 


\section{PATIK : JURNAL HUKUM Vol : 09 No. 2, Agustus 2020, Hal 125 - 136}

lebih memperhatikan tempat-tempat yang banyak ditinggali orang asing dan dilakukan pemeriksaan visa yang mereka gunakan saat tinggal di Indonesia.

Upaya yang dilakukan oleh kantor Imigrasi dalam rangka penegakan hukum terhadap penyalahgunaan izin tinggal di Provinsi Bali berupa (1) Langkah yang dilakukan oleh kantor Provinsi Bali dalam rangka penegakan hukum terhadap Penyalahgunaan izin tinggal adalah melakukan sosialisasi mengenai Undang-undang Nomor 6 Tahun 2011 Tentang Keimigrasian baik kepada warga negara Indonesia sendiri dan warga negara asing. (2) Pengawasan bagi orang asing tidak hanya dilakukan pada saat mereka masuk tetapi juga selama mereka berada di wilayah Indonesia termasuk kegiatan nya, pengawasan Keimigrasian mencakup penegakan hukum Keimigrasian baik yang bersifat administratif maupun tindak pidana Keimigrasian. (3) Dalam pemberian putusan hakim harus adanya 3 tujuan hukum yaitu menjamin kepastian hukum, keadilan dan kemanfaatan hukum.

\section{DAFTAR PUSTAKA}

Barda Nawawi Arief, Bunga Rampai Kebijakan Hukum Pidana, Citra Aditya Bakti, 1996

Bambang Poernomo, Asas-Asas Hukum Pidana, Ghalia Indonesia, 1994

Erdianto Effendi, 2011, Hukum Pidana Indonesia, Refika Aditama, Bandung

Frans Maranis, Hukum Pidana Umum Dan Tertulis Di Inonesia, Rajawali Pers, 2012

Laden Marpaung, Kejahatan Terhadap Kesusilaan Dan Masalah Prevensinya, Sinar Grafika, Jakarta, 2008

Mahsur Ali, Dasar- Dasar Hukum Pidana, Sinar Grafika, Jakarta Timur, 2012, Hal. 156

M. Iman Santoso, Prespektif Imigrasi, Bandung, Pustaka Reka Cipta, 2014Martias Gelar

Imam Radjo Mulano, Pembahasan Hukum, Penjelasan, Istilah Istilah Hukum Belanda, Ghalia, Jakarta, 1982

Manullang, H., Sitanggang, R., Sidauruk, S., \& Sinaga, E. (2020). PENYELESAIAN TINDAK PIDANA BIASA BERMOTIF RINGAN DENGAN RESTORATIF JUSTICE SEBAGIAN BENTUK UPAYA PEMBAHARUAN HUKUM PIDANA. Nommensen Journal of Legal Opinion, 1(01), 64-77. https://doi.org/10.51622/njlo.v1i01.39

Moelyatno, Perbuatan Pidana dan Pertanggungjawaban dalam Hukum Pidana, Bina Aksara, Jakarta, 1983, Hal: 22-23

P.A.F Lamintang, 1997, Dasar-Dasar Hukum Pidana Indonesia, Cetakan Tiga, Citra Aditia Bakti, Bandung

Peter Mahmud Marzuki, Penelitian Hukum, Kencana, Jakarta, 2005

Riduan Syahrani, 1999, Rangkuman Intisari Ilmu Hukum, . Citra Aditya Bakti, Bandung

Simamora, Janpatar., Tafsir Makna Negara Hukum dalam Perspektif Undang-Undang Dasar Negara Republik Indonesia Tahun 1945, Jurnal Dinamika Hukum FH Universitas Jenderal Soedirman, Vol. 14 No. 3 September 2014.

Sudarsono, 1994, Pengadian Negeri, Pengadilan Tinggi, MA dan Peradilan Tata Usaha Negara, Rineka Cipta, Jakarta,

Teguh Prasetyo, 2010, Hukum Pidana, Raja Grafinfo Persada, Jakarta

Zainal Abidin Farid, 2007, Hukum Pidana I, Cetakan Ke Dua, Sinar Grafika, Jakart 